\title{
PEMANFAATAN LOSSES MINYAK KERNEL (MINYAK INTI) SEBAGAI BAHAN BAKU PEMBUATAN SABUN PADAT
}

\section{UTILIZATION OF KERNEL OIL LOSSES (PALM KERNEL OIL) AS ROW MATERIAL FOR MAKING SOLID BATH SOAP}

\author{
Melki Edo Sinabang, Hasan Basri Daulay* , Bosman Sidebang, dan Devi Silsia \\ Jurusan Teknologi Pertanian, Fakultas Pertanian, Universitas Bengkulu \\ *Email korespondensi: hasanbasridaulay@gmail.com
}

Diterima 13-03-2021, diperbaiki 20-05-2021, disetujui 31-05-2021

\begin{abstract}
Processing of palm kernels at the kernel station of the palm oil mill still has a loss of kernel oil in the bulk silo kernel. This oil can be used as a raw material for solid soap. This study aims to determine the characteristics of solid soap resulting from core oil losses in terms of physical, chemical and organoleptic parameters and to obtain the right concentration of $\mathrm{NaOH}$ and fragrance oil volume to produce solid soap according to SNI 06-3532-2016. This study used a completely randomized design (CRD) with 2 factors, namely the concentration of $\mathrm{NaOH}$ and the amount of fragrance oil. The variables observed were water content test, foam stability, free alkaline content, $p H$ level, and organoleptic test. Solid soap characteristics are : moisture content $10.22 \%$ - 39.17\%, foam stability $45.93 \%-69.4 \%$, free alkaline content $0.16 \%-0.42 \%, \mathrm{pH} 9,86-13,31$. Panelist acceptance rates for texture $3-4.05$, color 3.3 - 4.05, aroma 3.1 - 3, 85 and oerall 3.35 - 4, 05.Soaps made with $20 \% \mathrm{NaOH}$ and $2 \mathrm{ml}$ fragrance oil has met SNI 06-3532-2016.
\end{abstract}

Keywords: palm kernel oil, solid bath soap and fragrance oil

\begin{abstract}
ABSTRAK
Pengolahan kernel di stasiun inti PMKS menghasilkan losses minyak inti sawit pada kernel bulk. Minyak ini dapat dimanfaatkan sebagai bahan baku sabun padat. Penelitian ini bertujuan menentukan karakteristik sabun padat yang dihasilkan dari losses minyak inti dilihat dari parameter fisik, kimia dan organoleptik dan untuk mendapatkan konsentrasi $\mathrm{NaOH}$ dan volume fragrance oil yang tepat untuk menghasilkan sabun padat yang sesuai dengan SNI 06-3532-2016. Penelitian ini menggunakan rancangan acak lengkap (RAL) dengan 2 faktor yaitu konsentrasi $\mathrm{NaOH}$ dan jumlah fragrance oil. Variabel yang diamati adalah uji kadar air, stabilitas busa, kadar alkali bebas, kadar $\mathrm{pH}$, dan uji organoleptik. Sabun padat yang dihasilkan dari losses minyak inti sawit memiliki karakteristik kadar air 10,22 \% - 39,17\%, stabilitas busa 45,93\% - 69,4\%, kadar alkali bebas 0,16 \% - 0,42\%, pH 9,86 - 13,31. Tingkat penerimaan panelis untuk tekstur 3-4,05, warna 3,3-4,05, aroma 3,1-3, 85 dan oerall 3,35-4, 05. Sabun yang dibuat dengan $\mathrm{NaOH} 20 \%$ dan fragrance oil $2 \mathrm{ml}$ sudah memenuhi SNI 06-3532-2016.
\end{abstract}

Kata kunci: minyak inti sawit, sabun padat dan fragrance oil 


\section{PENDAHULUAN}

PT. Daria Dharma Pratama adalah pabrik pengolahan kelapa sawit yang mengolah tandan buah segar (TBS) sebanyak 45 ton /jam. Dari pengolahan TBS tersebut dihasilkan produk utama yaitu minyak kelapa sawit (CPO) crude palm oil dan inti kelapa sawit (palm kernel). Produksi kernel di PT. Daria Dharma Pratama mencapai $4,77 \%$ per tahun.

Kernel merupakan bagian terpenting kedua setelah mesokarp, karena dari kernel inilah dihasilkan kernel palm oil (PKO) sebagai produk unggulan kedua setelah CPO (Subha, 2018). Proses pengolahan kernel meliputi pemisahan serabut dan biji dan pemisahan cangkang dengan inti sawit (kernel). Proses pengolahan kernel berakhir pada kornel bulk silo. Standar mutu kernel yang ditetapkan oleh PT Daria Dharma Pratama adalah kadar air maksimal 7\%, kadar kotoran maksimal $7 \%$ dan inti pecah maksimal $15 \%$. Hasil penelitian Subha (2018) menunjukkan bahwa mutu kernel yang dihasilkan belum memenuhi target, terutama kadar inti pecah. Tingginya kadar inti pecah mengakibatkan banyaknya tetesan minyak inti (losses minyak inti) di kernel bulk. Selama ini minyak ini belum dimanfaatkan dan hanya terbuang begitu saja.

Minyak inti sawit (palm kernel oil) ini dapat dimanfaatkan menjadi sabun. Menurut Prasetiyo, dkk (2020), kandungan utama dari minyak inti sawit adalah asam laurat yaitu sebesar 46-52\%. Asam laurat memiliki sifat mengeraskan, membersihkan, menghasilkan busa dan melembutkan dimana ketiga sifat ini sangat dibutuhkan pada sabun.

Sabun adalah bahan pembersih yang dibuat dengan mereaksikan senyawa basa (natrium atau kalium) dengan asam lemak dari minyak nabati dan atau lemak hewani. Sabun yang terbentuk bisa berbentuk padat, lunak ataupun cair. Untuk meningkatkan penerimaan bisa ditambahkan zat pewangi atau bahan lainnya yang tidak berbahaya terhadap kesehatan (BSN, 2016). Standar mutu sabaun padat menurut SNI 06-3532-
2016 adalah : kadar air (\%) maksimal $15 \%$, jumlah asam lemak bebas $(\%)>70$ untuk tipe 1 dan $64-70 \%$ untuk tipe II, alkali bebas sebagai $\mathrm{NaOH}$ maks $0,1 \%$, asam lemak bebas $(\%)<2,5$ dan minyak mineral negatif.

Kandungan senyawa yang terdapat dalam sabun sangat bervariasi, sesuai dengan jenis dan sifat sabun yang diinginkan. Larutan Natrium hidroksida $(\mathrm{NaOH})$ digunakan untuk membuat sabun padat, sedangkan untuk membuat sabun lunak digunakan larutan kalium hidroksida (KOH). (Naomi, 2013). Untuk meningkatkan kualitas dan penerimaan terhadap sabun mandi, maka diperlukan bahan tambahan seperti pengharum (pewangi) (Suwito, 2013).

Fragrance adalah salah satu zat aditif yang yang dapat ditambahkan pada produk cleansing, untuk meningkatkan penerimaan konsumen. Fragrance dapat menutupi karakteristik bau dasar dari asam lemak atau fase minyak. Fragrance yang ditambahkan tidak boleh merubah kestabilan dari produk akhir. Jumlah fragrance yang ditambahkan pada pembuatan sabun padat bervariasi, tergantung pada kebutuahn dan keinginan konsumen, jumlahnya berkisar dari $0,3 \%$ hingga 1,5\% (Barel et al, 2014).

Losses minyak inti yang terdapat di stasiun kernel dapat dijadikan bahan baku untuk membuat sabun padat. Konsentrasi $\mathrm{NaOH}$ dan penambahan fragrance oil yang tepat untuk menghasilkan sabun padat yang bermutu baik belum diketahui. Penelitian ini bertujuan menentukan karakteristik sabun padat yang dihasilkan dari losses minyak inti dilihat dari parameter fisik, kimia dan organoleptik dan untuk mendapatkan konsentrasi $\mathrm{NaOH}$ dan volume fragrance oil yang tepat untuk menghasilkan sabun padat yang sesuai dengan SNI 06-3532-2016.

\section{METODE PENELITIAN}

Penelitian ini dilakukan di Laboratorium Teknologi Pertanian, Fakultas Pertanian, Universitas Bengkulu,.Alat yang digunakan dalam penelitian ini adalah oven (memmer), timbangan digital (YP6001N 
electronic balance), hot plate (hotplate dan magnetic stirrer basic series), desikator, $\mathrm{pH}$ meter (adwa AD10), kertas saring (kertas saring lembaran ukuran $0,45 \mu \mathrm{m})$, termometer (termometer batang $\mathrm{Hg}$ ), cetakan dan alat gelas. Bahan yang digunakan dalam penelitian ini adalah minyak inti sawit, fragrance oil (java soap), aquades, etanol, $\mathrm{NaOH}, \mathrm{KOH} 0,1 \mathrm{~N}, \mathrm{HCl} 0,1$ $\mathrm{N}$ dan indikator phenolphtalein.

\section{Rancangan Penelitian}

Rancangan penelitian yang digunakan adalah Rancangan Acak Lengkap (RAL) dengan 2 faktor. Faktor pertama, adalah konsentrasi $\mathrm{NaOH}$ yang terdiri dari 3 taraf yaitu $20 \%$, 30\% dan $40 \%$ faktor kedua adalah jumlah fragrance oil yang terdiri dari 3 taraf yaitu: $1 \mathrm{ml}, 1,5 \mathrm{ml}$ dan $2 \mathrm{ml}$. Penelitian ini masing-masing diulang sebanyak 3 kali pengulangan, sehingga diperoleh 27 unit percobaan.

\section{Tahapan Penelitian}

\section{Persiapan Bahan Baku}

Pada tahap ini dipersiapkan bahan baku yaitu losses minyak inti sawit yang diambil dari stasiun pengolahan kernel PT. Daria Dharma Pratama, fragrance oil (java soap) dan bahan kimia lainnya dalam membuat sabun padat.

\section{Pemurnian Minyak Inti Sawit}

Sebelum digunakan sampel (minyak inti sawit) dimurnikan terlebih dahulu, dengan cara penyaringan. Penyaringan dilakukan untuk memisahkan kotoran pada minyak inti sawit dengan cara minyak dipanaskan sampai mencapai suhu $80^{\circ} \mathrm{C}$ diukur menggunakan termometer dan kemudian disaring dengan menggunakan kertas saring (kertas saring lembaran ukuran

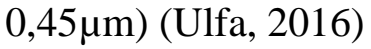

\section{Tahapan Pembuatan Sabun padat}

Tahapan-tahapan pembuatan sabun padat sebagai berikut Minyak inti sawit sebanyak $2000 \mathrm{~g}$ dipanaskan menggunakan hotplate hingga mencapai suhu $70^{\circ} \mathrm{C}$. Kemudian ditambahkan larutan $\mathrm{NaOH}$ dengan kosentrasi 20\%, $30 \%$, dan $40 \%$ (sesuai perlakuan) kedalam campuran minyak sedikit demi sedikit sambil diaduk sampai homogen dan terjadi trace (kondisi sabun sudah terbentuk dengan tanda massa sabun mengental). Setelah terjadi trace, suhu adonan diturunkan sampai mencapai suhu $\pm 50^{\circ} \mathrm{C}$ lalu ditambahkan fragrance oil sesuai perlakuan. Campuran tersebut diaduk sampai terbentuk campuran yang homogen. Selanjutnya diangkat dan dituangkan dalam cetakan, kemudian didiamkan selama 24 jam dalam suhu ruang.

\section{Variabel Pengamatan \\ Kadar Air}

Sampel sabun ditimbang sebanyak 4 gram dan ditimbang berat wadahnya. Selanjutnya dipanaskan dalam oven pada suhu $105^{\circ} \mathrm{C}$ selama 2 jam, lalu didinginkan dalam desikator, kemudian ditimbang kembali. Prosedur tersebut diulang sampai didapat berat yang konstan. Kadar air dihitung dengan rumus sebagai berikut (SNI 06-3532-2016):

$$
\begin{aligned}
& \text { Keterangan: } \\
& W_{1}=\text { berat sampel }+ \text { wadah sebelum } \\
& \text { dikeringkan }(\mathrm{g}) \\
& W_{2}=\text { berat sampel }+ \text { wadah setelah } \\
& \text { dikeringnkan }(\mathrm{g}) \\
& \mathrm{W}=\text { berat sampel }(\mathrm{g})
\end{aligned}
$$$$
\text { Kadar air }=\frac{\mathrm{W}_{1}-\mathrm{W}_{2}}{\mathrm{~W}} \times 100 \%
$$

\section{Stabilitas Busa}

Tinggi busa diukur setiap 5 menit selama 15 menit berturut-turut untuk mengamati konsentrasi keberadaan busa. Sampel ditimbang sebanyak $1 \mathrm{~g}$, dimasukkan kedalam tabung reaksi dan ditambahkan akuades sebanyak $10 \mathrm{ml}$. Campuran tersebut dikocok dengan membolak-balikan tabung reaksi. Selanjutnya diukur tinggi busa yang dihasilkan. Tabung reaksi didiamkan selama 5 menit, kemudian diukur lagi tinggi busanya. Stabiltas busa diukur dengan rumus berikut: (Pradipto, 2009).

Stabilitas busa $(\%)=\frac{\text { tinggi busa akhir }}{\text { tinggi busa awal }} \times 100 \%$ 


\section{Kadar Alkali Bebas}

Alkohol sebanyak $100 \mathrm{ml}$ didihkan dalam labu erlenmeyer $250 \mathrm{ml}$. Selanjutnya ditambahkan $0,5 \quad \mathrm{ml}$ indikator phenolphtalein dan didinginkan sampai suhu $70^{\circ} \mathrm{C}$ kemudian dinetralkan dengan $\mathrm{KOH}$ $0,1 \mathrm{~N}$ dalam alkohol. Selanjutnya masukan 5 gram sabun dan didihkan di atas penangas air selama 30 menit. Apabila larutan tidak berwarna merah, campuran tersebut didinginkan sampai suhu $70^{\circ} \mathrm{C}$ dan selanjutnya dititrasi dengan larutan $\mathrm{KOH}$ 0,1 N dalam alkohol, sampai timbul warna yang tetap selama 15 detik. Apabila larutan berwarna merah maka dititrasi menggunakan $\mathrm{HCl} \mathrm{0,1} \mathrm{N}$ dalam alkohol dari mikro buret, sampai warna merah cepat hilang dan hasilnya dihitung dengan rumus (SNI 06-3532-2016):

Alkali bebas $=\frac{40 \times V \times N}{b} \times 100 \%$

Keterangan:

$\mathrm{V}=$ volume $\mathrm{HCl}$ yang digunakan

$\mathrm{N}=$ normalitas $\mathrm{HCl}$ yang digunakan

$\mathrm{b}=$ berat contoh sampel

$40=$ berat ekuivalen $\mathrm{NaOH}$

\section{Derajat Keasaman (pH)}

Ambil $5 \mathrm{~g}$ sabun kemudian larutkan dengan $5 \mathrm{ml}$ aquades. Ukur $\mathrm{pH}$ sabun dengan $\mathrm{pH}$ meter dan dicatat $\mathrm{pH}$ yang dihasilkan (SNI 06-3532-2016).

\section{Uji Organoleptik}

Pada pengujian organoleptik ini dilakukan oleh panelis semi terlatih sebanyak 20 orang untuk memberikan penilaian dengan skala hedonik terhadap tingkat penerimaan dan kesukaan dalam segi tekstur, warna, aroma dan tingkat kesukaan secara keseluruhan (overall). Tingkat skala hedonik yang digunakan dari skala suka (5), agak suka (4), netral (3), agak tidak suka (2) dan tidak suka (1). Hasil uji hedonik ditabulasikan dalam tabel (Widyasanti, 2017).

\section{Analisis Data \\ Data yang didapatkan dari hasil penelitian dianalisis dengan menggunakan metode Analysis of Variance (ANOVA) dua arah, Hasil analisis yang menujukkan perbedaan yang nyata dilanjutkan dengan uji lanjut DMRT (Duncan's Multiple Range Test) pada taraf signifikan 5\% menggunakan SPSS 24.}

\section{HASIL DAN PEMBAHASAN}

\section{Kadar Air}

Analisa kadar air perlu dilakukan untuk mengetahui kadar air yang terdapat dalam sabun padat. Kualitas sabun akan dipengaruhi oleh kadar air. Menurut Hambali, dkk, (2005) kelarutan sabun dipengaruhi oleh air yang ditambahkan pada proses pembuatannya. Qisti (2009) menyatakan apabila kandungan air pada sabun terlalu tinggi maka akan menyebabkan sabun mudah menyusut dan tidak nyaman saat digunakan. Nilai ratarata kadar air sabun padat yang dihasilkan dapat dilihat pada Gambar 1.

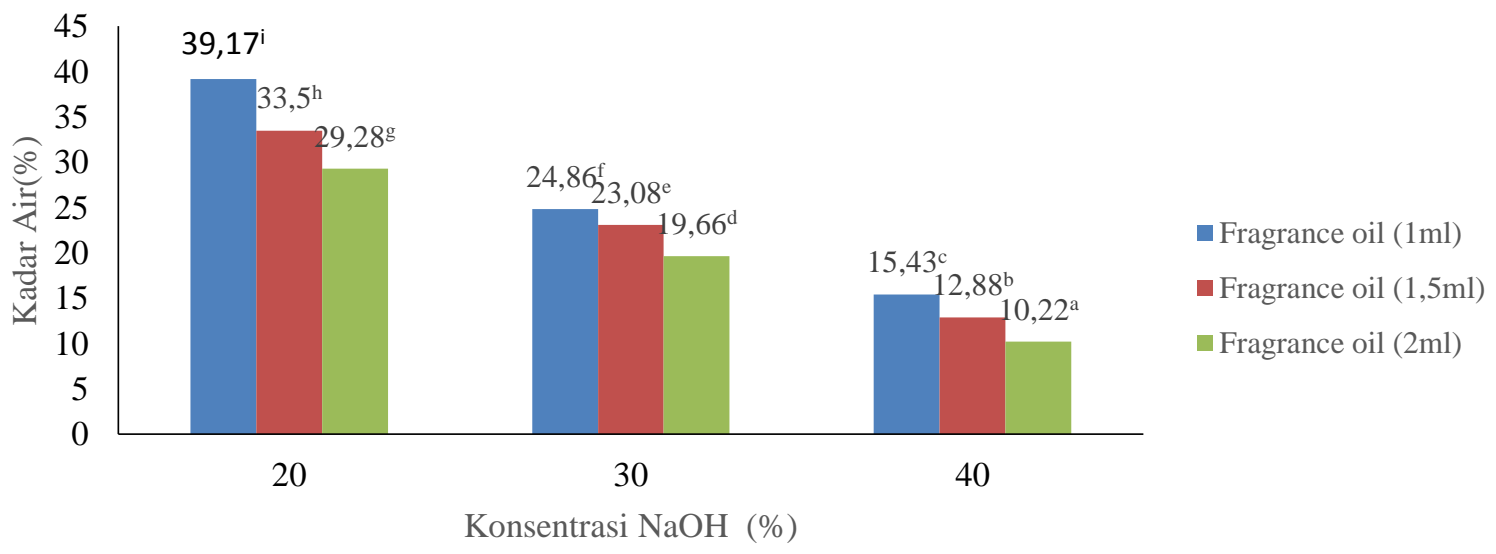

Gambar 1. Kadar air sabun padat pada berbagai konsentrasi $\mathrm{NaOH}$ dan penambahan fragrance oil. 
Hasil ANOVA pada taraf 5\% menunjukkan bahwa perlakuan penambahan $\mathrm{NaOH}$ dan fragrance oil berpengaruh nyata terhadap nilai kadar air sabun dengan taraf signifikan $0,00<0,05$. Dari hasil uji lanjut dengan DMRT (Duncan's Multiple Range Test) pada taraf 5\% dapat diketahui bahwa perlakuan $\mathrm{NaOH}$ dengan konsentrasi $20 \%$ dan fragrance oil (1 ml, 1,5 $\mathrm{ml}$ dan $2 \mathrm{ml})$ berbeda nyata dengan konsentrasi $\mathrm{NaOH}$ $30 \%$ dan $40 \%$. Makin tinggi konsentrasi $\mathrm{NaOH}$ dan jumlah fragrance oil, maka kadar air sabun yang dihasilkan makin menurun. Hasil penelitian sejalan dengan penelitian Baiq, (2014). Jika konsentrasi $\mathrm{NaOH}$ semakin tinggi, maka air yang ditambahkan semakin sedikit, dan jumlah air di dalam sabun juga sedikit (Sukeksi, dkk, 2018). Dari Gambar 1 dapat dilihat bahwa kadar air yang sudah memenuhi SNI 06-3532-2016 adalah perlakuan $\mathrm{NaOH} 40 \%$ dan fragrance oil 1,5 ml dan $2 \mathrm{ml}$.

\section{Stabilitas Busa}

Pengukuran stabilitas busa bertujuan untuk mengetahui kestabilan busa yang dihasilkan oleh sabun. Menurut Widyasanti (2017) stabilitas busa adalah kemampuan suatu bahan penghasil busa untuk mempertahankan busa yang dihasilkan. Kecepatan pembentukan busa dan stabilitas busa merupakan dua hal penting untuk produk pembersih tubuh. Busa berperan dalam proses pembersihan dan melimpahkan wangi sabun pada kulit. Nilai stabilitas busa yang dihasilkan pada penelitian ini dapat dilihat pada Gambar 2.

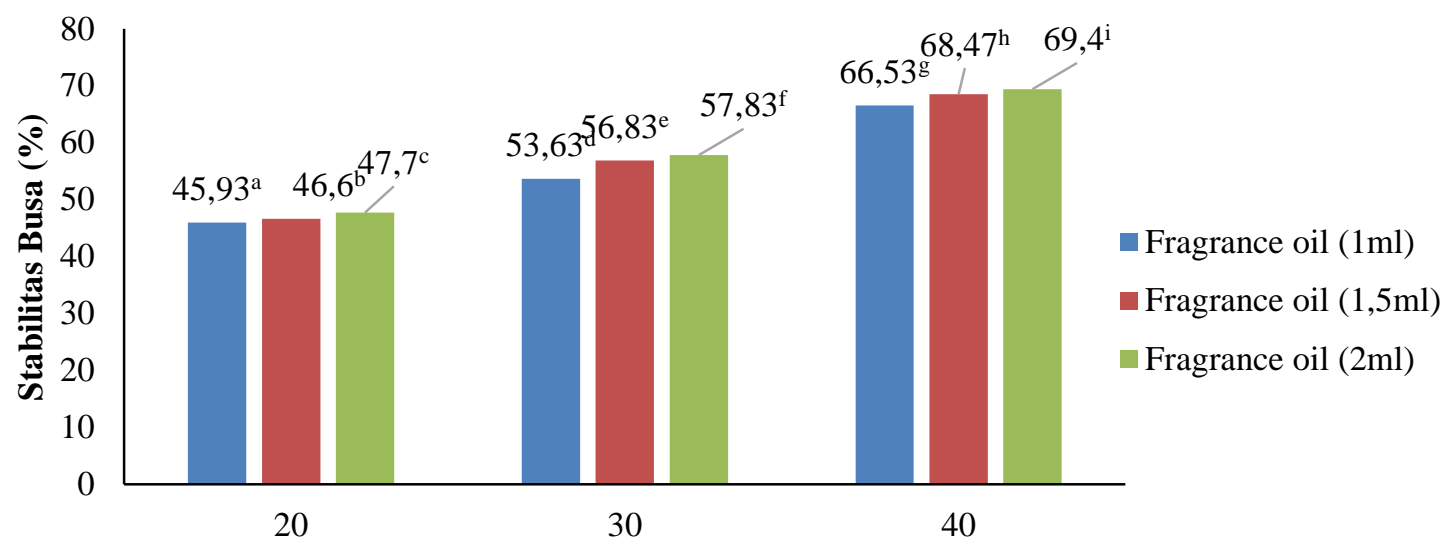

Konsentrasi NaOH (\%)

Gambar 2. Stabilitas busa sabun padat pada berbagai konsentrasi $\mathrm{NaOH}$ dan penambahan fragrance oil.

Hasil ANOVA pada taraf 5\% menunjukkan bahwa perlakuan penambahan $\mathrm{NaOH}$ dan fragrance oil berpengaruh nyata terhadap nilai stabilitas busa sabun mandi dengan taraf signifikan $0,00<0,05$. Uji lanjut DMRT (Duncan's Multiple Range Test) pada taraf 5\% menunjukkan bahwa perlakuan $\mathrm{NaOH}$ konsentrasi $20 \%$ dan fragrance oil (1 ml, 1,5 $\mathrm{ml}$ dan $2 \mathrm{ml})$ berbeda nyata. Sedangkan perlakuan $\mathrm{NaOH}$ konsentrasi $30 \%$ dan fragrance oil $(1 \mathrm{ml}, 1,5$ $\mathrm{ml}$ dan $2 \mathrm{ml}$ ) berbeda nyata dan pada perlakuan $\mathrm{NaOH}$ konsentrasi $40 \%$ dan fragrance oil ( $1 \mathrm{ml}, 1,5 \mathrm{ml}$ dan $2 \mathrm{ml})$ berbeda nyata. Stabilitas busa yang diperoleh pada penelitian ini berkisar antara 45,93-69,4 (\%).
Alkali Bebas
Alkali bebas adalah alkali dalam sabun yang tidak terikat dengan asam lemak membentuk garam asam lemak (sabun). Berdasarkan SNI 06-3532-2016 kadar alkali bebas dalam sediaan sabun padat maksimal $0,1 \%$. Jika kadar alkali bebas terlalu tinggi, dapat menyebabkan kulit teriritasi. Menurut Hambali, dkk (2005) jika pada proses safonifikasi konsentrasi alkali yang digunakan terlalu pekat dan berlebih, maka 
kandungan alkali bebasnya akan tinggi. Nilai rata-rata kadar alkali bebas sabun padat

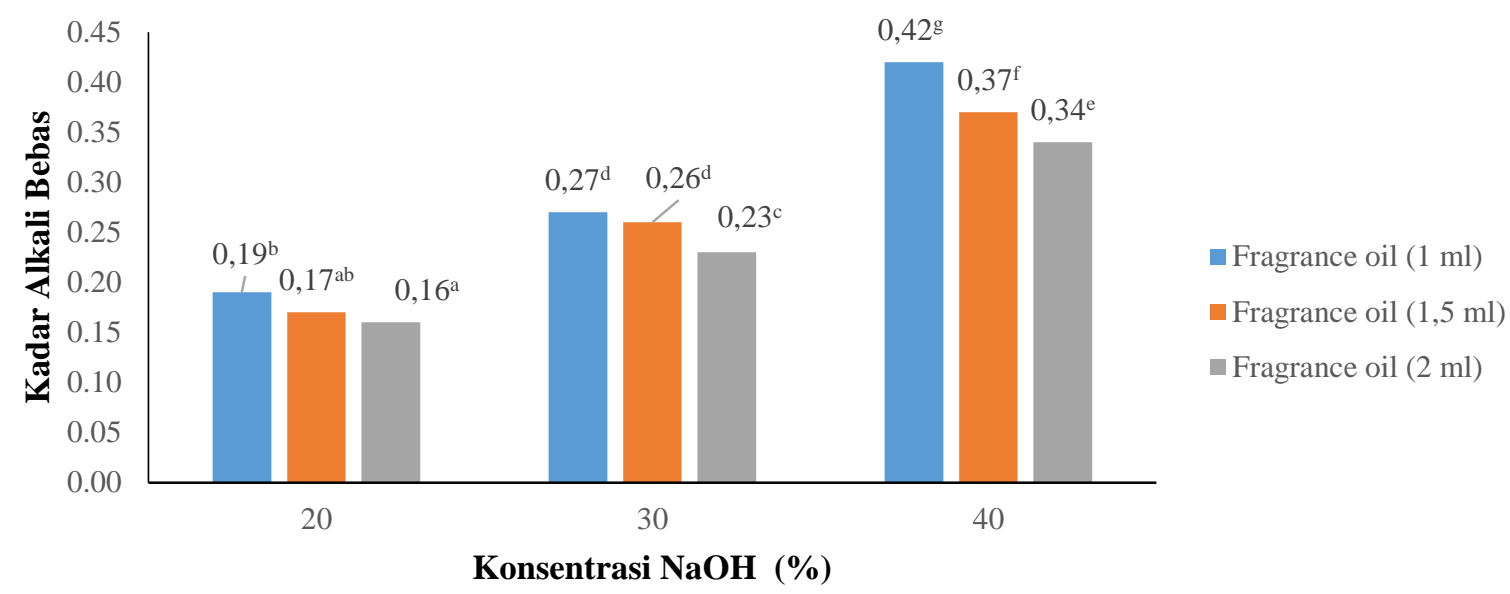

yang dihasilkan dapat dilihat pada Gambar 3.

Gambar 3. Kadar alkali bebas sabun padat pada berbagai konsentrasi $\mathrm{NaOH}$ dan penambahan fragrance oil.

Hasil ANOVA pada taraf 5\% menunjukkan bahwa perlakuan penambahan $\mathrm{NaOH}$ dan fragrance oil berpengaruh nyata terhadap nilai kadar alkali bebas sabun padat dengan taraf signifikan $0,01<0,05$. Uji lanjut DMRT (Duncan's Multiple Range Test) pada taraf 5\% menunjukkan bahwa perlakuan $\mathrm{NaOH}$ konsentrasi $20 \%$ dan fragrance oil ( $\mathrm{I} \mathrm{ml}, 1,5 \mathrm{ml}$ dan $2 \mathrm{ml}$ ). berbeda nyata dengan perlakuan konsentrasi $\mathrm{NaOH}$ $30 \%$, fragrance oil (I ml, 1,5 $\mathrm{ml}$ dan $2 \mathrm{ml}$ ) serta konsentrasi $\mathrm{NaOH} 40 \%$, fragrance oil (I ml, 1,5 $\mathrm{ml}$ dan $2 \mathrm{ml}$ ).

Gambar 3 menunjukkan bahwa makin tinggi konsentrasi $\mathrm{NaOH}$ makin besar kadar alkali bebas sabun yang dihasilkan. Begitu juga makin banyak jumlah fragrance oil yang ditambahkan, makin tinggi kadar alkali bebas. Menurut Prihanto dan Irawan (2018) jika konsentrasi $\mathrm{NaOH}$ ditingkatkan, maka kemungkinan jumlah $\mathrm{NaOH}$ yang bersisa di 


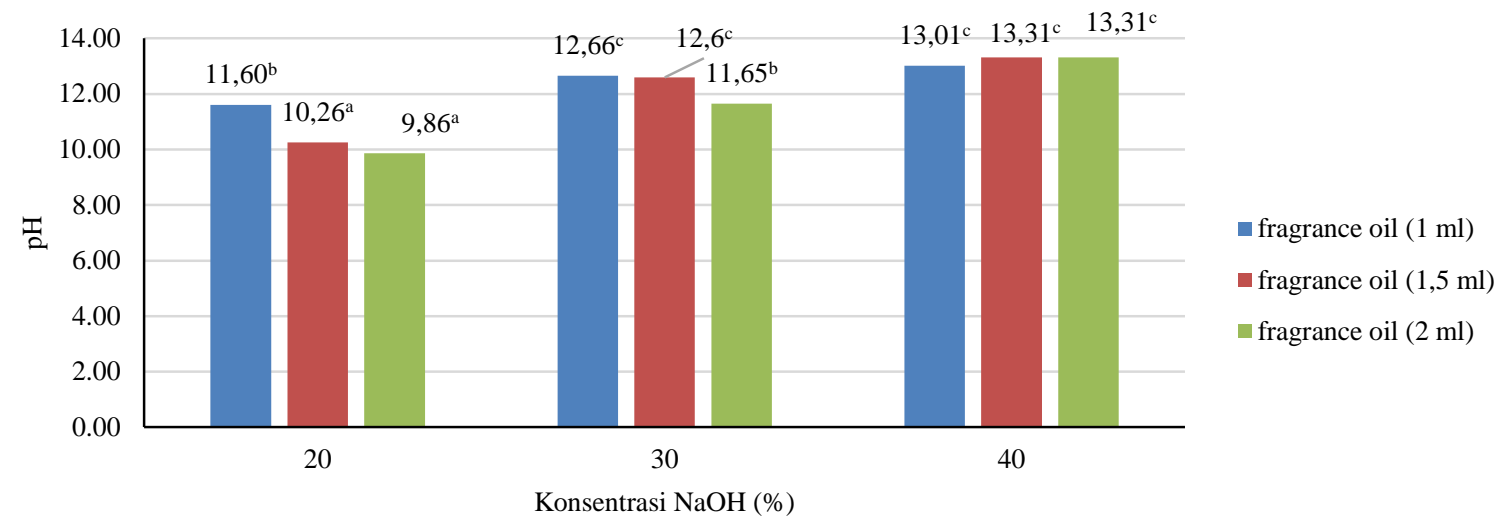

Gambar 4. Kadar $\mathrm{pH}$ sabun padat pada berbagai konsentrasi $\mathrm{NaOH}$ dan penambahan fragrance oil.

Hasil analisis ANOVA pada taraf 5\% menunjukkan bahwa penambahan $\mathrm{NaOH}$ dan fragrance oil berpengaruh nyata terhadap nilai $\mathrm{pH}$ sabun padat yang dihasilkan dengan taraf signifikan 0,02 lebih kecil dari 0,05. Uji lanjut DMRT (Duncan's Multiple Range Test) pada taraf 5\% menunjukkan bahwa perlakuan $\mathrm{NaOH}$ kadar konsentrasi $20 \%$ dan fragrance oil $(1,5 \mathrm{ml}$ dan $2 \mathrm{ml}$ ) berbeda tidak nyata, namun pada Fragrance oil $(1 \mathrm{ml})$ berbeda nyata. Sedangkan perlakuan $\mathrm{NaOH}$ konsentrasi $30 \%$ dan fragrance oil $(1 \mathrm{ml}$ dan $1,5 \mathrm{ml})$ berbeda tidak nyata, namun pada fragrance oil $(2 \mathrm{ml})$ berbeda nyata. Pada konsentrasi $\mathrm{NaOH} 40 \%$ dan fragrance oil $(1 \mathrm{ml}, 1,5$ dan $2 \mathrm{ml})$ juga berbeda tidak nyata.

Hasil pengamatan pada penelitian sabun padat dengan bahan baku utama minyak inti sawit menunjukkan nilai $\mathrm{pH}$ sabun padat antara 9,86-13,31. Sabun yang beredar di pasaran umumnya memiliki $\mathrm{pH} 9$ - 10,8. Menurut Almazini (2009) jika pH sabun terlalu tinggi akan menyebabkan kulit kering dan meningkatkan pertumbuhan bakteri. Hal ini karena pada $\mathrm{pH}$ tinggi dapat terjadi pembekakan keratin sehingga bakteri mudah masuk, kulit menjadi kering dan pecah-pecah. Tetapi jika $\mathrm{pH}$ terlalu rendah dapat menyebabkan kulit menjadi iritasi.

\section{Tingkat Penerimaan Panelis terhadap Tekstur Sabun Padat}

Tekstur sabun padat dipengaruhi oleh kadar air. Jika kadar air tinggi, maka tesktur sabun menjadi lunak, dan jika kadar air rendah maka sabun tersebut memiliki struktur yang keras (Widyasanti, 2017). Dari hasil uji yang dilakukan, diperoleh nilai rata-rata penerimaan panelis terhadap aroma sabun padat dengan skala hedonik 3 sampai 4,05 antara netral hingga agak suka. Nilai rata-rata kesukaan panelis terhadap tekstur sabun padat yang dihasilkan dapat dilihat pada Gambar 5. 


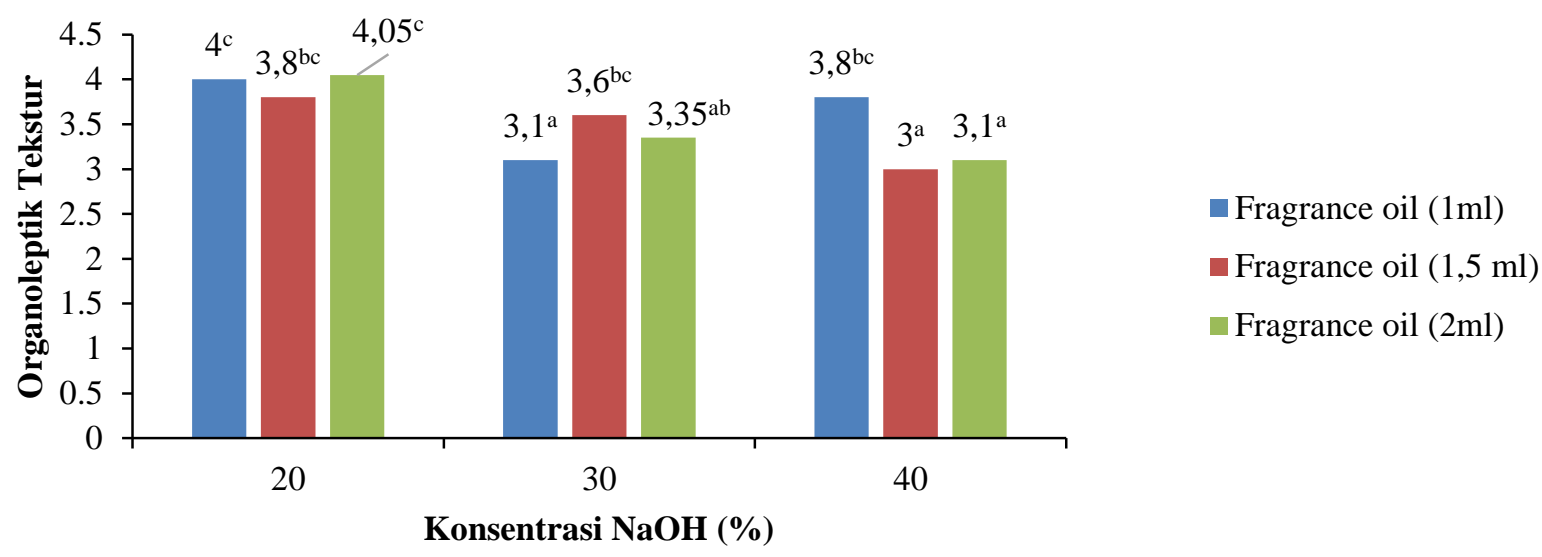

Gambar 5. Penerimaan Panelis terhadap tekstur sabun pada berbagai konsentrasi $\mathrm{NaOH}$ dan penambahan fragrance oil.

Hasil ANOVA pada taraf 5\% menunjukkan bahwa perlakuan penambahan $\mathrm{NaOH}$ dengan fragrance oil berpengaruh nyata terhadap organoleptik tekstur maka perlu dilanjutkan dengan uji DMRT pada taraf 5\%. Hasil lanjut uji DMRT (Duncan's Multiple Range Test) pada taraf 5\% menunjukkan bahwa tingkat penerimaan terhadap tekstur untuk sabun dengan konsentrasi $\mathrm{NaOH} 20 \%$ dengan $\mathrm{NaOH} 30$ dan $40 \%$. Tekstur sabun yang paling disukai panelis terdapat pada perlakuan $\mathrm{NaOH}$ konsentrasi $20 \%$ dan penambahan fragrance oil $2 \mathrm{ml}$ dengan skala hedonik 4,05 pada kisaran agak suka hingga suka.

Gambar 5 menunjukkan bahwa penerimaan terhadap struktur sabun menurun dengan meningkatnya konsentrasi $\mathrm{NaOH}$. Tingkat kesukaan panelis terendah terhadap tekstur sabun padat terdapat pada perlakuan $\mathrm{NaOH}$ konsentrasi $40 \%$ dengan penambahan fragrance oil $1,5 \mathrm{ml}$ dengan skala hedonik 3 yaitu netral. Tingkat kesukaan tertinggi terdapat pada perlakuan
$\mathrm{NaOH}$ konsentrasi $20 \%$ dengan penambahan fragrance oil $2 \mathrm{ml}$ dengan skala hedonik yaitu 4.05. Tekstur sabun padat dipengaruhi oleh banyaknya $\mathrm{NaOH}$ yang digunakan. Jika jumlah konsentrasi $\mathrm{NaOH}$ tinggi, akan menghasilkan sabun yang semakin padat (Hambali dkk, 2005).

\section{Tingkat Penerimaan Panelis terhadap Warna Sabun Padat}

Pengujian warna terhadap sabun padat dilakukan untuk mengetahui tingkat penerimaan produk. Suwito (2013) menyatakan warna merupakan salah satu parameter yang dapat digunakan untuk menilai suatu produk, pengujian warna dilakukan dengan uji organoleptik. Dari hasil uji yang telah dilakukan, diperoleh nilai rata-rata penerimaan panelis terhadap warna sabun padat dengan skala hedonik 3,3 sampai 4,05 antara netral hingga agak suka. Nilai rata-rata penerimaan panelis terhadap warna sabun padat yang dihasilkan dapat dilihat pada Gambar 6. 


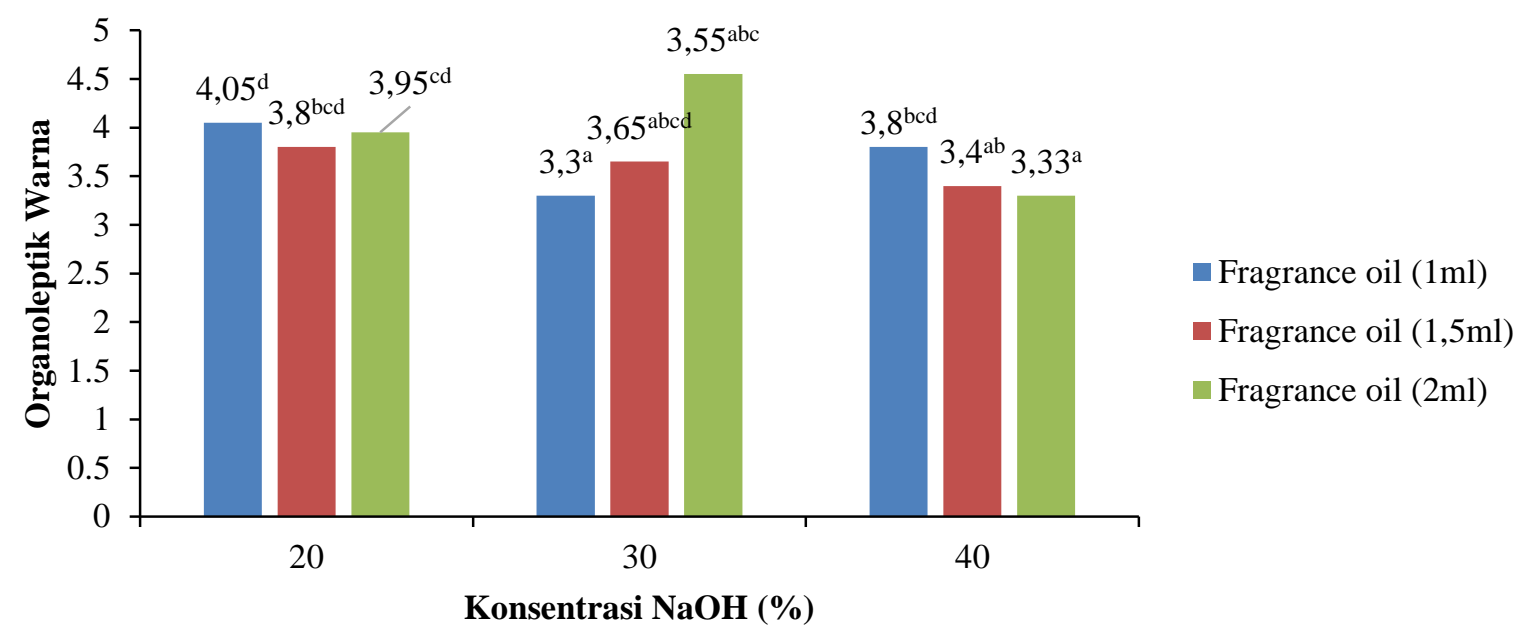

Gambar 6. Penerimaan Panelis terhadap warna sabun pada berbagai konsentrasi $\mathrm{NaOH}$ dan penambahan fragrance oil.

Hasil ANOVA pada teraf 5\% menunjukkan bahwa tingkat penerimaan terhadap warna dipengaruhi oleh konsentrasi $\mathrm{NaOH}$ dan fragrance oil . Hasil uji lanjut DMRT (Duncan's Multiple Range Test) pada taraf 5\% menunjukkan bahwa tingkat penerimaan terhadap warna pada konsentrasi $\mathrm{NaOH} 20 \%$ berbeda dengan $\mathrm{NaOH} 30 \%$ dan $40 \%$. Warna sabun yang paling disukai panelis terdapat pada perlakuan $\mathrm{NaOH} 50 \mathrm{ml}$ dengan konsentrasi $30 \%$ dan fragrance oil $2 \mathrm{ml}$ dengan skala hedonik 4,55 pada kisaran agak suka hingga suka.

\section{Tingkat Penerimaan Panelis terhadap Aroma Sabun Padat}

Aroma merupakan salah satu faktor penting pada sabun padat untuk menarik minat konsumen. Sabun yang memiliki aroma harum dan tahan lama lebih disukai oleh konsumen (Fathoni, 2019). Rata-rata penerimaan panelis terhadap aroma sabun padat berada pada skala 3,1-3,85 (antara netral hingga agak suka),seperti terlihat pada Gambar 7.

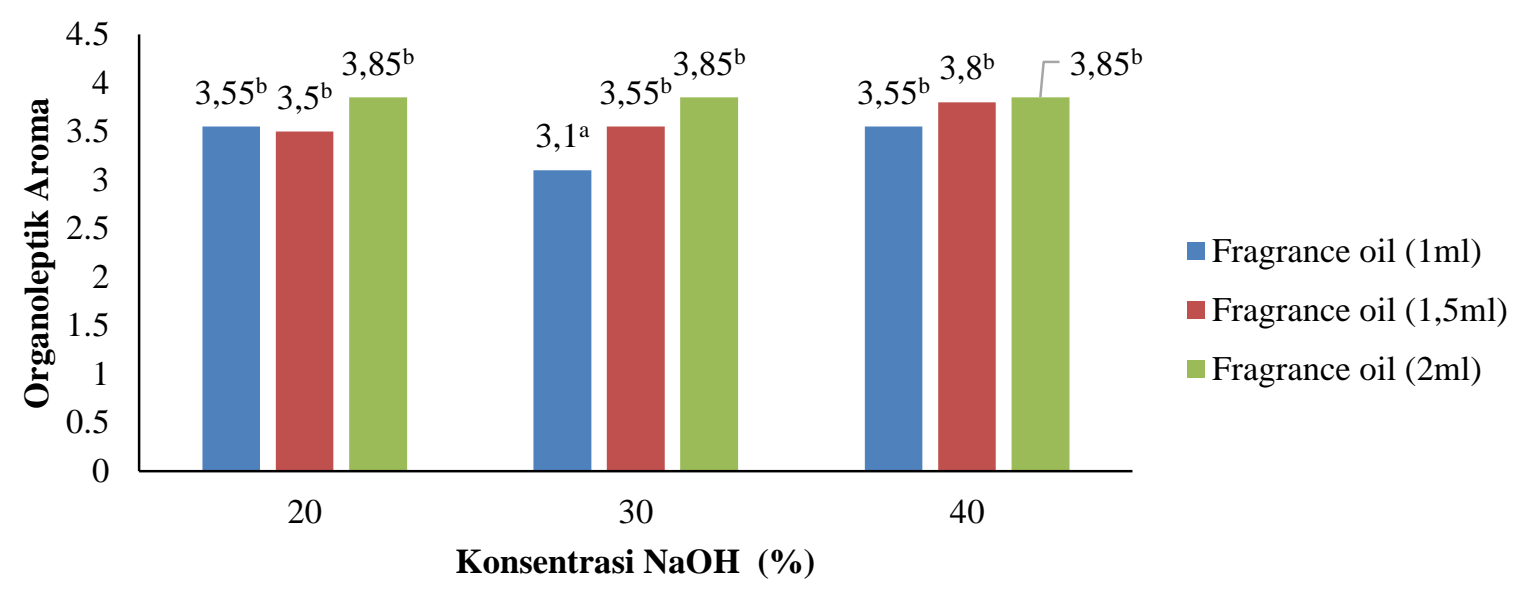

Gambar 7. Penerimaan Panelis terhadap aroma sabun pada berbagai konsentrasi $\mathrm{NaOH}$ dan penambahan fragrance oil. 
Hasil ANOVA pada taraf 5\% menunjukkan bahwa konsentrasi $\mathrm{NaOH}$ dan jumlah fragrance oil berpengaruh nyata terhadap tingkat penerimaan aroma. Uji lanjut DMRT pada taraf 5\% memperlihatkan bahwa perlakuan $\mathrm{NaOH}$ dengan konsentrasi $30 \%$ dan fragrance oil $1 \mathrm{ml}$ berbeda nyata dengan perlakuan lainnya.

Tingkat kesukaan panelis terhadap aroma sabun padat yang memiliki nilai terendah terdapat pada perlakuan $\mathrm{NaOH} 50$ $\mathrm{ml}$ dengan konsentrasi $30 \%$ dengan fragrance oil $1 \mathrm{ml}$ dengan skala hedonik 3,1 yaitu antara netral hingga agak suka. Tingkat kesukaan tertinggi terdapat pada perlakuan
$\mathrm{NaOH} 50$ ml dengan konsentrasi 20\%, 30\% dan $40 \%$ dengan penambahan fragrance oil $2 \mathrm{ml}$ yaitu dengan skala hedonik 3,85 yaitu antara netral hingga agak suka.

\section{Tingkat Penerimaan Panelis Secara Keseluruhan (overall)}

Overall merupakan gabungan dari tampak seperti tekstur, warna dan aroma. Dari hasil uji yang telah dilakukan diperoleh nilai 3,35 hingga 4,05 (antara netral sampai agak suka). Gambar 8 menunjukkan nilai rata-rata tingkat kesukaan keseluruhan panelis overall terhadap sabun.

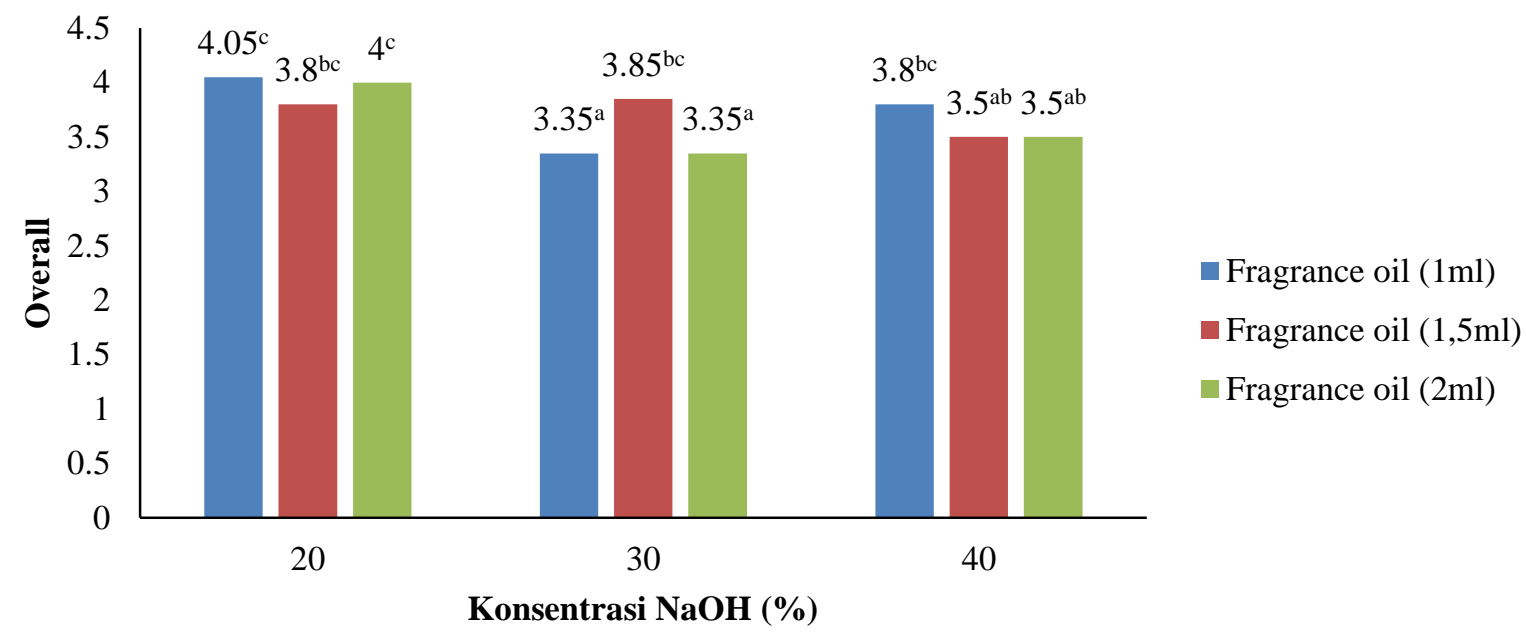

Gambar 8. Penerimaan Panelis secara keseluruhan (over all) sabun pada berbagai konsentrasi $\mathrm{NaOH}$ dan penambahan fragrance oil.

Hasil ANOVA pada taraf 5\% menunjukkan bahwa konsentrasi $\mathrm{NaOH}$ dan fragrance oil berpengaruh nyata terhadap tingkat kesukaan sabun secara keseluruhan (overall). Uji lanjut DMRT pada taraf 5\% memperlihatkan bahwa perlakuan $\mathrm{NaOH}$ konsentrasi $20 \%$ dan fragrance oil $1 \mathrm{ml}, 1,5$ $\mathrm{ml}$ dan $2 \mathrm{ml}$, perlakuan $\mathrm{NaOH} 30 \%$ dan fragrance oil 1,5 Ml serta $\mathrm{NaOH} 40 \%$ dan fragrance oil $1 \mathrm{ml}$ berbeda tidak nyata, namun berbeda nyata dengan perlakuan lainnya.

Tingkat kesukaan secara keseluruhan (overall) terhadap sabun padat yang memiliki nilai terendah terdapat pada perlakuan $\mathrm{NaOH} 30 \%$ dan fragrance oil $1 \mathrm{ml}$ dan $2 \mathrm{ml}$ dan $\mathrm{NaOH}$ konsentrasi $40 \%$ dan fragrance oil 1,5 $\mathrm{ml}$ dan $2 \mathrm{ml}$ dengan skala hedonik 3,35 ( netral dan agak suka), sedangkan nilai tertinggi terdapat pada perlakuan $\mathrm{NaOH}$ konsentrasi $20 \%$ dan fragrance oil $1 \mathrm{ml}$ dengan skala hedonik 4,05 (agak suka dan suka).

\section{KESIMPULAN}

Karakteristik sabun padat yang dihasilkan dari losses minyak inti sawit adalah: kadar air 10,22 \% - 39,17 \%, stabilitas busa $45,93 \%$ - 69,4 \%, kadar alkali bebas $0,16 \%$ - 0,42 \%, pH 9,86-13,31. Tingkat penerimaan panelis untuk tekstur 3 
- 4,05, warna 3,3 -4,05, aroma 3,1 - 3, 85 dan oerall $3,35-4,05$. Sabun yang yang dihasilkan dari perlakuan $\mathrm{NaOH} 20 \%$ dan fragrance oil $2 \mathrm{ml}$ sudah memenuhi SNI 063532-2016.

\section{DAFTAR PUSTAKA}

Baiq, R. M. (2014). Pengaruh Konsentrasi $\mathrm{NaOH}$ Terhadap Kualitas Sabun Padat Dari Minyak Kelapa (Cocos Nucifera) yang Ditambahkan Sari Bunga Mawar (Rosa L.). Jurnal Pendidikan Kimia. 1(2), 41-46.

Barel, A. O. M. Paye and H. Maibach. (2014). Handbook of Cosmetic Science and Technology. $3^{\text {rd }}$ ed. Informa Healthcare USA, Inc. New York. 6: 485-491 hal.

BSN. (2016). SNI 06-3532-2016. Sabun padat. Badan Standarisasi Nasional. Jakarta.

Fathoni, D. (2019). Kajian Pembuatan Sabun Mandi Cair Dari Campuran CPO dengan Penambahan Minyak Atsiri Jeruk Kalamansi. Skripsi. Fakultas Pertanian. Universitas Bengkulu, Bengkulu.

Hambali. E., T. Bunasor dan G. Kusuma. (2005). Aplikasi Dietanolamida dari Asam Laurat Minyak Inti Sawit Pada Pembuatan Sabun Transparan. Jurnal Teknologi Industri Pertanian. 15(2), 46-53.

Naomi, P., Gaol, A. M dan Toha, Y. (2013). Pembuatan Sabun Lunak dari Minyak Goreng Bekas Ditinjau dari Kinetika Reaksi Kimia. Jurnal Teknik Kimia. 2(19), 42-48.

Prasetiyo, A. (2020). Formulasi Sabun Padat Transparan dari Minyak Inti Sawit. Jurnal Jamu Indonesia. 5(2), 39-44.

Prihanto, A dan B. Irawan. (2018). Pemanfaatan Minyak Goreng Bekas
Menjadi Sabun Mandi. Jurnal Metana. 14(2), 54-59.

Qisti, R. (2009). Sifat Kimia Sabun Transparan Dengan Penambahan Madu Pada Konsetrasi Yang Berbeda. Skripsi. Jurusan Teknologi Hasil ternak. Fakultas Peternakan. Institut Pertanian Bogor. Bogor.

Sadiyah, N. (2018). Formulasi Sabun padat Berbasis Minyak Biji Kapuk Randu (Ceiba pentandra Gaertn) Dengan Penambahan Jasmine Oil. Jurnal Inovasi Teknik Kimia. 3(2), 8-14.

Sukeksi, L., M. Sianturi dan L. Setiawan. (2018). Pembuatan Sabun Trasnsparan Berbasis minyak kelapa dengan penambahan ekstarak buah mengkudu (morinda citrifolia) sebagai bahan antioksidan. Jurnal Teknik Kimia. 7(2), 33-39.

Suwito. (2013). Tingkat Penerimaan Panelis Terhadap Sifat Organoleptik Sabun Trasnparan yang Diformulasikan dari Minyak Sawit dengan Penambahan Pewarna dan Pewangi. Skripsi. Fakultas Pertanian. Universitas Riau. Riau.

Ulfah, M., A. Ruswanto dan Ngatirah. (2016). Karakteristik Minyak ampuran dari Red Palm Oil dengan Palm Kernel Olein. Agritech. 36 (2), 145-151.

Widyasanti, A., D. Nugraha dan D. Rohdian. (2017). Pembuatan Sabun Padat Transparan Berbasis Bahan Minyak Jarak (Castrol oil) Dengan Penambahan Bahan Aktiv Ekstrak Teh Putih (Camelia Sinesis). Jurnal Ilmu-Ilmu Pertanian. 1(2), 140-151. 